\title{
Judicial Reasoning and Review in the Indonesian Supreme Court
}

\author{
Simon BUTT* \\ University of Sydney Law School, Camperdown, NSW, Australia
}

\begin{abstract}
This article describes and critiques the judicial reasoning of Indonesia's Supreme Court, through the lens of the Court's reviews of subnational laws during 2011-17. The resulting picture is a negative one. Most of the Court's decisions were critically flawed, with either very little or no reasoning, and inconsistencies with past decisions. Worse, the Court appears keen to avoid hearing important cases that raise difficult political issues, even though the law governing those issues is clear and easy to apply. These inadequacies are perpetuated by genuine uncertainty about the precise jurisdiction of the Court in judicial review cases. However, the Court has not sought to resolve this uncertainty. Indeed, these decisions appear to reflect a court paying little regard to judicial transparency and accountability, and unwilling or unable to act as an effective check on government power.
\end{abstract}

Keywords: Indonesia, judicial review, Supreme Court, regional autonomy, judicial reasoning

\section{INTRODUCTION}

In mid-2017, Indonesia's Constitutional Court issued two decisions that reconfigured the relationship between Indonesia's national government on the one hand and its 34 provincial and over 500 city and county governments on the other. Before the decisions, the national government - through the Ministry of Home Affairs — could review and invalidate all laws passed by subnational governments (known as Perda, short for "peraturan daerah") if they were inconsistent with national laws, the public interest, or morality. The ministry had delegated this power to governors to review and, if necessary, invalidate the laws passed by city and county governors, on the same grounds. In these two decisions, the Constitutional Court removed these powers. One of the reasons the Constitutional Court gave was that reviewing subnational laws made by democratically elected local governments and executives was not a matter for a higher tier of government, but rather was a matter for the courtsparticularly the Supreme Court, which had already been reviewing these types of subnational law as part of its broader judicial review jurisdiction.

* Professor of Indonesian Law at the University of Sydney Law School. Correspondence to Simon Butt, The University of Sydney Law School, Building F10, University of Sydney, Camperdown, NSW 2006, Australia. E-mail address: Simon.butt@sydney.edu.au. 
The Constitutional Court's decisions in these cases have caused significant controversy, not least because important parts of its decisions were not legally convincing, and the Court appeared to be evenly split, with four judges each in the majority and in the minority. In this article, I leave these criticisms aside, significant though they are. ${ }^{1}$ Instead, I focus on the Constitutional Court's solution—giving exclusive jurisdiction to Indonesia's Supreme Court to review subnational laws. Of course, having a professionally run review mechanism is critical in decentralized Indonesia, where local governments have sweeping law-making powers, but some appear to have been misusing them, and where the jurisdictional boundaries are often hotly contested. However, some of the Supreme Court's decision-making practices-evident in the judicial review cases involving subnational laws it heard in the years before the Constitutional Court's decisions were issued-raise grave concerns about the prudence of giving the Supreme Court this exclusive power.

Questions have long been raised about the quality of the Supreme Court's decisionmaking and integrity in general ${ }^{2}$ and in its judicial review cases in particular. ${ }^{3}$ For example, its judicial reviews are decided behind closed doors, and usually without oral argument. According to some commentators, this reduces transparency, enabling unscrupulous parties to seek to illegally influence the Court's decisions without the knowledge of other parties to the dispute. ${ }^{4}$ The Court's decision-making in review cases has been subject to very little scholarly attention, primarily because the Supreme Court had made very few of its judicial review decisions available to the public. The studies that have been produced are generally very critical. For example, some studies have found that the Court is generally reluctant to exercise its review powers, but that, when it does, it often fails to demonstrate that it has considered the parties' arguments, is reluctant to examine the merits of the case, issues decisions inconsistent with previous decisions, and often provides few or even no reasons for its holdings. ${ }^{5}$ In recent years, many more review decisions have appeared on the Court's website, now making it possible to provide a more comprehensive picture of the Court's judicial review jurisprudence. ${ }^{6}$ This article seeks to provide precisely this, drawing on more than 50 judicial review cases. These represent all judicial reviews of Perda available on the Court's website that were lodged with the Court during 2011-17, and a handful of earlier cases. Using these newly obtainable data, this article confirms that these previously identified decision-making problems remain and uncovers more still.

In summary, my findings are as follows. In a handful of Perda reviews, the Court has issued decisions that are clear and logical. However, these are the exception rather than the

\footnotetext{
1. For a full critique of this decision, see Butt (2018).

2. For example, see Pompe (2005); Butt \& Lindsey (2010); Aspandi (2002); STPMH (2010); Parlina \& Dipa (2013).

3. Parsons \& Mietzner (2010); Butt \& Parsons (2014); Butt (2010); Sholikin (2013). The enforceability of decisions of Indonesia's courts, including the Supreme Court, has been brought into question by some scholars, but mainly in civil and criminal cases; see Butt (2008). I am unaware of any cases where local governments have refused to comply with Supreme Court judicial review decisions. However, it bears noting that Article 8 of Supreme Court Regulation 1 of 2011 on Judicial Review states that, if the relevant official refuses to comply with a Supreme Court judicial review decision within 90 days of receiving an official copy of that decision, then the legal instrument the Court invalidated will automatically no longer have legal effect.

4. Fachrudin (2017).

5. Butt \& Parsons, supra note 3; Butt, supra note 3; Effendi (2013).

6. I have based this analysis on my reading of just under 60 of these cases. While more than 100 cases appear on the Court's website in search results for judicial review of Perda, many of them contain no links or dead links to the case file, making them impossible to include in the analysis.
} 
norm, and even these decisions have scant reasoning. The cases support two broad observations. The first is that the Supreme Court remains generally reluctant to perform its judicial review function, at least in Perda cases. While this observation is not new of itself, it can now be more convincingly substantiated on grounds not uncovered in previous studies: its relatively strict approach to standing in most cases, its regular use of technicalities to throw out applications, and its avoidance of highly charged political disputes, even where the law governing that dispute and that law's application to the dispute are very clear. The second is that almost all Supreme Court Perda review decisions contain at least one critical flaw in approach or reasoning. Most are exceptionally short, and many are vague, providing no information about how the Court reached them. Some provide incomplete or superficial reasoning, and others no reasoning at all. Many decisions contradict others.

Before turning to discuss the Supreme Court decisions that shaped these observations, I introduce the key features of regional autonomy, and the Indonesian Supreme Court and its judicial review powers, in the context of the programme of reform that occurred in the postSoeharto period. After describing the Supreme Court's judicial review jurisprudence in cases involving subnational laws, I then offer some explanations for the deeply flawed and underdeveloped nature of that jurisprudence. As we shall see there, many factors likely affect Supreme Court judges' decision-making beyond a "pure" application of the law.

\section{POST-SOEHARTO REFORM, REGIONAL AUTONOMY, AND THE SUPREME COURT}

Within a few years of Soeharto's fall, Indonesia had embarked upon regional autonomy, or decentralization, reforms. ${ }^{7}$ These were an important component of much broader reforms to dismantle the authoritarian system Soekarno introduced from 1959 and Soeharto maintained during his presidency (1966-98). For much of Soeharto's rule in particular, power was highly concentrated within the presidency, and was abused for the personal gain of Soeharto himself, his family, and his "cronies." 8 As his reign progressed, discontent grew about military-led violence and human rights abuses, and the general disenfranchisement of the population. ${ }^{9}$ When many of the economic and social gains made under his authoritarian rule were unravelled by the 1997 Asian Economic Crisis, calls for democratic reforms became so strong and sustained that many observers and even Indonesian politicians feared that Indonesia would "Balkanize" unless far-reaching and genuine reforms were made. ${ }^{10}$ The political system was overhauled through constitutional amendments and statutory reforms that, inter alia, established new human rights protections, a more powerful parliament (installed after free and fair elections), anti-corruption reforms, and the "de-militarization" of politics. ${ }^{11}$ Judicial reforms were also achieved, including transferring government control over judicial administration to the Supreme Court (the so-called satu atap, or one roof, reforms), and

7. The first statutory bases for these reforms were Law 22 of 1999 on Regional Government and Law 25 of 1999 on Fiscal Balance between the Central and Regional Governments. The former was replaced by Law 32 of 2004 on Regional Government, which was then replaced by Law 23 of 2014 on Regional Government.

8. Schwarz (2000).

9. Thoolen (1987); Lubis (1993).

10. Horowitz (2013); Crouch (2010).

11. Hosen (2010); Butt \& Lindsey (2012). 
establishing the Constitutional Court, to act as a check on the exercise of government power, particularly that of the national legislature. ${ }^{12}$

Regional autonomy should be seen in the context of this broader reform programme, which sought to disperse the power previously held in the hands of the presidency among various national and subnational individuals and institutions. Strongly supported by donors, the decentralization reforms were directed at bringing government "closer to the people," with the hope that this might improve government accountability and transparency. ${ }^{13}$ Under these reforms, significant powers were devolved from the central government to provincial, city, and county administrations. Each of these subnational tiers has a democratically elected local legislature (Dewan Perwakilan Rakyat Daerah). Each also has an executive head and deputy: in provinces, governors (gubernur); in cities, mayors (walikota); and in counties, regents (bupati). These legislatures and executives were given responsibility over a wide variety of matters, including health, education, infrastructure, transport, land, environmental matters and the like, and power to make laws about these matters. These laws are called "regional regulations" (Peraturan Daerah, or Perda) and encompass regulations and decisions issued by these subnational parliaments and executives. The central government retained power over foreign affairs, fiscal and monetary policy, judicial matters, defence and security, and religion, and has largely retained power to override these local regulations with national laws. ${ }^{14}$ It was also anticipated that local governments might need assistance from the central government, given that almost all of them lacked experience in making policy and translating that policy into law. After all, under Soeharto, regional governments were entrusted with little more than ensuring that the central government's wishes were followed in the regions. Accordingly, the central governmentparticularly the Ministry of Home Affairs-was thus also entrusted with overseeing aspects of the performance of subnational governments, including checking that their laws were consistent with national laws and did not violate the public interest or morality. Having these powers of central oversight as part of these reforms was quickly vindicated, as many local governments initially exercised their law-making powers almost exclusively to raise revenue in ways that some commentators considered to be predatory. ${ }^{15}$

As mentioned, the Constitutional Court has since removed the ministry's powers to review Perda, once enacted, ${ }^{16}$ deciding instead that Perda review should be performed by a judicial institution - in this case, the Supreme Court (Mahkamah Agung), which is the country's apex court in non-constitutional matters. ${ }^{17}$ It hears appeals, or cassation applications, from

12. Butt (2015); Hendrianto (2009); Asshiddiqie (2008). Many of the reforms to the Supreme Court followed a blueprint produced by the Supreme Court in collaboration with the non-governmental organization (NGO) Lembaga Kajian dan Advokasi untuk Independensi Peradilan (LeIP, or Institute for the Study of and Advocacy for Judicial Independence); Mahkamah Agung (2003).

13. See Ahmad \& Mansoor (2002); ADB (2005); Bird (2007); Manor (1999); Litvack et al. (1998); Tanzi (1995). Whether the regional autonomy laws have established subnational governments that meet these expectations is a matter of some dispute. Some commentators claim that governance standards have worsened, but others point to improvements in health and education in some regions. See Pratikno (2005); Kristiansen \& Santoso (2006); Ahmad et al. (2005); Arnold (2009); Hill (2014); Lieberman \& Marzoeki (2002); Barr (2006); Lewis \& Pattinasarany (2009); Bedner (2010).

14. Article 10(1) of the 2014 Regional Autonomy Law.

15. Ray (2003); Lewis (2003); Ismail (2003); Butt \& Parsons (2012); Lewis \& Sjahir (2009).

16. There remains some scope for the central government to review some types of Perda before their enactment. These include Perda establishing local budgets, taxes, and spatial plans.

17. By contrast, the Constitutional Court performs "constitutional review"- that is, it ensures that legislation complies with the Constitution including the human rights adopted in the second amendment in 2000. The Court also has jurisdiction to resolve disputes about the relative jurisdiction of state institutions, the dissolution of political parties, and 
Indonesia's high courts and, in some matters, directly from first-instance courts, of which there are four branches. These are the general courts, which hear most civil and criminal matters; the religious courts, which hear Islamic family-law disputes; the administrative courts; and the military courts. ${ }^{18}$

The Court has other statutory and constitutional functions. One of these is judicial review. The Supreme Court has had this power for several decades, ${ }^{19}$ but largely refused to exercise it because of the almost complete judicial dependence on government, from at least the late 1950s until Soeharto's fall in $1998 .^{20}$ From 1999 , however, reforms were put in motion aimed at making the Supreme Court and the courts it oversees independent from government, and institutional independence was achieved from $2004 .^{21}$ Since then, the Court appears to have been hearing between 50 and 80 judicial review cases per year. ${ }^{22}$

However, there remains much uncertainty about the precise scope of the Supreme Court's judicial review power and, consequently, whether it will exercise it in any given case. Explaining why requires discussion of Indonesia's so-called "hierarchy of laws." The Constitution and various judiciary laws refer to the Supreme Court having power to review laws "below" statutes. The word "below" here appears to be a reference to the hierarchy, which lists legal instruments commonly issued in Indonesia, apparently in order of their authority. Contained in Article 7(1) of the 2011 Law-making Law, ${ }^{23}$ the hierarchy is as follows:

1. The 1945 Constitution (Undang-undang Dasar 1945);

2. Decrees of the People's Consultative Assembly (Ketetapan MPR);

3. Statutes/Interim Emergency Laws (Undang-Undang/Peraturan Pemerintah Pengganti Undang-Undang);

4. Government Regulations (Peraturan Pemerintah);

5. Presidential Regulations (Peraturan Presiden);

6. Provincial Regulations (Peraturan Daerah Propinsi); and

\section{County/City Regulations (Peraturan Daerah Kabupaten/Kota).}

Each type of law must not conflict with any law higher than its own type in the hierarchy; and one type of law can amend or revoke a law lower than its own type in the hierarchy. So, for example, a provincial regulation will be legally valid—at least formally—only if, when

\section{(F'note continued)}

general election results. It must also "provide a decision" if the national Parliament suspects that the president or vice president has committed treason or corruption, another serious crime or form of misconduct, or otherwise no longer fulfils the constitutiona requirements to hold office. See Article 24C(1) and (2) of the 1945 Constitution and Article 10 of Law 24 of 2003 on the Constitutional Court.

18. See Butt \& Lindsey (2018).

19. Lev (1978).

20. Pompe, supra note 2; Lev (1972). The Court can also perform formal review (uji formil) - that is, assess whether the process by which a law came into being complied with legislative requirements. See Article 31(2) of Law 14 of 1985. The Court has decided very few of these cases and they are not discussed here.

21. Hosen, supra note 11 .

22. Butt \& Parsons, supra note 3; Mahkamah Agung (2015).

23. Law 12 of 2011 on Law-making. 
passed, it does not contradict a presidential regulation, government regulation, statute, People's Consultative Assembly decree, or the Constitution. Once passed, it is susceptible to override by any of those higher-level instruments. Many lower-level laws are said to derive legal legitimacy from a higher-level law. For example, many regional government regulations are issued in response to a provision of a national statute or presidential regulation that directs the regional government to issue that regulation, usually to provide further details about a matter covered very generally in the statute or presidential regulation. ${ }^{24}$

How the hierarchy does, or even should, operate is a matter of some uncertainty and dispute in Indonesia, partly because the hierarchy does not explain its operation and Indonesian courts have provided no consistent guidance. Central to the problem is that the hierarchy leaves out many types of laws regularly used in Indonesia. The hierarchy acknowledges this, stipulating that officials or government institutions have power to enact a legal instrument with binding legal force if power is delegated to them by a higher-level law or the subject matter of the instrument otherwise falls within their jurisdiction (Article 8). However, the precise legal authority of the types of laws anticipated by Article 8 - especially vis-à-vis laws that are listed on the hierarchy and vis-à-vis other types of laws deriving their authority from Article 8-is not explained and is hence unclear. This uncertainty is brought into sharp relief in the case of ministerial regulations, which are not mentioned on the hierarchy, but are very commonly issued. The Home Affairs Minister has issued many regulations purporting to outline the responsibilities of local governments, limit the exercise of their powers, and (before the 2017 Constitutional Court decisions, at least) even to invalidate Perda. However, because the authority of ministerial regulations to override a Perda is highly contested and unresolved, some local governments have refused to be bound by those regulations and have continued to apply their Perda regardless. ${ }^{25}$

The uncertainty about the precise scope of the Supreme Court's judicial review powers is due to the Supreme Court's "material review" (uji materiil) jurisdiction being described differently in the Constitution, statutes, and Supreme Court regulations. According to Article 24A(1) of the Constitution, the Supreme Court has jurisdiction to review regulatory instruments "below a statute against statutes." This jurisdiction is restated in Article 20(2) of the 2009 Law on Judicial Power and Article 31(2) of the 1985 Supreme Court Law (as amended in 2004). Similarly, Article 7(2) of the Law-making Law states that "If a law below a statute is suspected of conflicting with a statute, its review is to be performed by the Supreme Court."

However, other provisions specify that the Court can review any law below a statute against any law higher than it on the hierarchy-and not necessarily a statute. Article 31(2) of the Supreme Court Law, for example, states that the "Supreme Court is to declare a law below a statute invalid if it conflicts with a higher-level law." Similarly, the Elucidation to Article 20(2) of the 2009 Judicial Power Law refers to "the Supreme Court's judicial power to review legal instruments lower than a statute. This can be performed against the substance of a Sub-article, Article or part of a higher-level law." Even vaguer is Article 5(2) of MPR

\footnotetext{
24. It is common for years to pass before such "implementing regulations" are issued, if they are issued at all. Current practice is that most legislative provisions that anticipate further regulations lie dormant until the regulations are passed - the courts will very rarely, if ever, "fill in the gaps" left by statutes.

25. Butt \& Parsons, supra note 3, pp. 68-70. For a view supporting the superior status of ministerial regulations, see Aziz (2010).
} 
Decision III/MPR/2000 on Sources of Law and the Hierarchy of Law, which describes the Court's jurisdiction as "reviewing regulatory instruments below statutes," without specifying against what. Finally, Supreme Court Regulation 1 of 2011 on Judicial Review specifies that judicial review is the "right of the Supreme Court to evaluate the substance of a law below a statute against a higher-level law" (Article 1(1)).

I am unaware of any judicial decision or academic writings that seek to reconcile these provisions. However, following the hierarchy itself, Article 24A(1) of the Constitution must prevail in the event of inconsistency, which means that the Supreme Court's jurisdiction must be confined to reviewing lower-level laws against statutes. As the Court's jurisdiction seems to be clearly delineated in Article 24A(1), there seems no need for further explanation to be provided in legislation or any other type of law. There can be no fault with the legislative instruments that simply confirm this constitutionally conveyed jurisdiction. But the provisions that seem to extend this to review any lower-level law against any higher-level law, including a statute, violate the Constitution.

Despite what appears to be a clear constitutional position, these inconsistent statutes and the regulation have led to confusion about whether the Supreme Court can only review lower-level laws against statutes or whether it can also review lower-level laws against each other. ${ }^{26}$ Resolving this uncertainty is central to the legal operation of regional autonomy. This is because the bulk of national law, including important rules on regional autonomy that purport to bind subnational governments, are contained in government and presidential regulations. If review of Perda for compliance with government and presidential regulations does not fall within the Supreme Court's jurisdiction, then these rules become largely unenforceable against local governments. However, rather than assist to revolve this confusion, the Supreme Court has perpetuated it. In some cases, the Court has thrown out review applications concerning alleged conflicts between laws below statutes, but in others it has decided them. ${ }^{27}$ The Court has not, to my knowledge, explained these inconsistencies.

\section{SUPREME COURT PERDA REVIEWS}

I now turn to discuss some of the decision-making practices that emerged from my reading of the more recently released Supreme Court Perda review cases, with a focus on the Court's reasoning or absence of it, and its refusal to review some types of Perda despite having no convincing legal reason to refuse. Before turning to discuss these issues, I note that one of the main criticisms levelled against the Supreme Court generally, and in judicial review cases, is that it regularly issues inconsistent decisions. This is widely reported in the media and has been highlighted in the Court's own research. ${ }^{28}$ One conspicuous area of inconsistency is the Court's approach to standing. As discussed below, the Court has, without explanation, interpreted its standing rules broadly in some cases and narrowly in others. The Court's research has identified an "inadequate consideration" of standing in "most" of its judicial review decisions, noting that some decisions have not even established the standing of the applicants before proceeding to the merits of the case. ${ }^{29}$

\footnotetext{
26. Butt \& Parsons, supra note 3.

27. Ibid.

28. Hukumonline (2002); Effendi, supra note 5.

29. Effendi, supra note 5, p. v.
} 
Perhaps even more fundamentally, the Supreme Court has also been inconsistent in deciding the types of laws it will review. This is a quite separate issue from those raised about the uncertainty of the Court's jurisdiction relating to the hierarchy of laws, discussed above. In most cases, the Court rejects applications seeking review of anything other than a "regulatory" instrument (peraturan) — that is, a law of general application. So, in some cases where applicants have sought to review gubernatorial decisions ${ }^{30}$ or even regent circular letters (surat edaran), ${ }^{31}$ the Court has refused, stating that its judicial review jurisdiction does not extend to those instruments: as administrative "decisions" (keputusan), they should instead be challenged in the administrative courts. Yet, in other cases, the Court has decided to review circular letters ${ }^{32}$ and gubernatorial decisions, either without further explanation ${ }^{33}$ or pointing to Article 8(1) of the Law-making Law. ${ }^{34}$ This provision gives legal authority to types of laws not mentioned on the hierarchy, but which are made pursuant to a delegation of authority or the inherent powers of the maker of the instrument. Using this as a legal basis for reviewing decisions is questionable because Article 8(1) refers only to regulations, not decisions.

\subsection{Scant or Poor Reasoning}

The Supreme Court's published Perda review decisions are usually 15 to 40 pages. On the first page appears the case file number; the formal title of the Perda to be reviewed and the law or laws with which that Perda allegedly conflicts; and the names of the applicant, the respondent, and their respective lawyers. Included next are the applicant's arguments (including about standing and the Perda's defects) and then the respondent's. Finally, the Court issues its reasoning (pertimbangan hukum) and its order (amar putusan). The bulk of most decisions comprises the parties' arguments, which the Court appears to simply copy into the judgment. The Court's legal reasoning is usually relatively short, in many cases comprising only two small paragraphs.

The Bogor Non-smoking Areas case $(2011)^{35}$ provides an example of reasoning so scant that understanding how the Court reached the decision is impossible from reading the judgment. Here, the applicants challenged Bogor City Perda 12 of 2009 on Non-Smoking Areas. Their arguments were not particularly convincing. They pointed out that, while the title of the Perda referred to non-smoking kawasan (areas), its text did not prohibit smoking in "areas," but rather only in and around sarana (facilities). This, the applicants argued, violated provisions of the 2011 national Law-making Law, which requires all laws to be clear in their purpose and formulation. The applicants also argued that restricting smoking violated smokers' constitutional rights. ${ }^{36}$ The Bogor government's arguments in response were much stronger. It pointed out that Article 115(2) of the national Health Law required local governments to regulate non-smoking areas $^{37}$ and that the Perda protected significant community interests. ${ }^{38}$

30. Supreme Court Decision 51 P/HUM/2012.

31. Supreme Court Decision $48 \mathrm{P} / \mathrm{HUM} / 2016$.

32. Supreme Court Decisions 23P/HUM/2009 \& 3P/HUM/2010; see also Hukumonline (2017).

33. Supreme Court Decision $01 \mathrm{P} / \mathrm{HUM} / 2014$.

34. Supreme Court Decision 14 P/HUM/2017, p. 19; Supreme Court Decision 65 P/HUM/2014.

35. Supreme Court Decision 39 P/HUM/2011.

36. Supreme Court Decision 39 P/HUM/2011, p. 17.

37. Law 36 of 2009 on Health.

38. Supreme Court Decision 39 P/HUM/2011, p. 21. 
The Court provided scant reasons, in dot points. Here is the entirety of those reasons, in my translation:

- It is not proved that the Perda violates principles of good law-making - that is, it accords with the clear aims and clear formulation principles.

- The purpose of the Law is providing public protection to the Bogor community.

- Article 6(2) of the Perda does not violate Government Regulation 19 of 2003, Law 39 of 2009, Law 12 of 2011 and the 1945 Constitution. ${ }^{39}$

In the Demak Village Head case (2016), ${ }^{40}$ the Court offered a slightly better, albeit incomplete, judgment. This case concerned the requirements for serving as a village head. The Perda in question had prohibited candidates from standing for election to that office if they had already been village head for 18 years or had served three terms of office. However, as the applicants pointed out, Article 39 of national Law 6 of 2014 on Villages provided that village heads could serve a maximum of three terms, and that each term was six years. The Court said:

From the objections of the applicants, connected with the evidence adduced, the Supreme Court is of the opinion: "That [the impugned provisions of the Perda] essentially regulate the requirements to stand again as village head, in connection with the duration of office based on time, whereas the [higher-level laws] regulate the requirements to stand again, in connection with the duration of office based on periodization." Therefore, the regulation [in the Perda] contains a new norm which is different from the intent of the norm as regulated in higher-level laws, and therefore has different legal consequences from the basic regulations. Therefore, [the impugned provisions] conflict with higher-level laws.

The Court then set out those higher-level laws.

While the Court has provided some reasons here, it is difficult to understand them without further information. The key difference between the Perda and the national village statute was that, under the statute, a village head could stand down or be dismissed before their term expired, and this would be counted as one term. Regardless, the applicant could only serve two more terms. By contrast, under the Perda, the applicants argued, a village head candidate could serve more than three terms if one of them was cut short, provided that, at the point of election, the candidate had not served as a village head for more than 18 years. This additional information was contained in the application, and was reported in the press, ${ }^{41}$ but does not appear in the Court's legal reasoning or order.

In some cases, the Court provided no reason for its decision, declaring simply that the application was "not proven or had no basis." 42 For example, in the Demak County Regulation case (2011), ${ }^{43}$ the Court concluded that the impugned Perda did not contradict a

39. Supreme Court Decision 39 P/HUM/2011, p. 33. I assume here that the Court's reference to Law 39 of 2009 was an error, and should be Law 36 of 2009, which is the Health Law and was discussed in argument, although it could also be a mistaken reference to Law 39 of 1999 on Human Rights, which largely mirrors rights contained in the Constitution and was also discussed by the applicants. Government Regulation 19 of 2003 concerns Smoking Safety for Health and was mentioned in argument by the applicant and the respondent.

40. Supreme Court Decision $30 \mathrm{P} / \mathrm{HUM} / 2016$.

41. See Almanaf (2017).

42. Supreme Court Decision $34 \mathrm{P} / \mathrm{HUM} / 2012$.

43. Supreme Court Decision $31 \mathrm{P} / \mathrm{HUM} / 2011$. 
higher-level law, as the applicant had alleged. The Court identified an apparently relevant higher-level law, but did not explain why it found no conflict, stating:

From the reasons for the applicant's objections connected with the evidence the application contains, the Supreme Court believes that the reasons for the applicant's objections cannot be accepted, for the following reasons:

The $[$ Perda] is clearly in line with and strengthens provisions of Government Regulation 45 of 2007, Articles 2, 3(1) and 10(1) .... Therefore, based on the above consideration the [Perda] does not violate a higher-level law-that is Government Regulation 45 of 2007 [and other lowerlevel ministerial regulations]. ${ }^{44}$

In other cases, the Court has invalidated a Perda for violating a higher-level law but has not identified that higher-level law in its reasoning or holding. The Medan Mayor Regulation case $(2013)^{45}$ provides an example of this. The applicant was the director of a company that built houses and had sought a permit to build on land the company owned. The Perda required that, to obtain a permit, ownership of the land needed to be proved with a photocopy of the land deed or certificate. The applicant had neither but did have a 2012 Supreme Court decision declaring that the company owned the land. ${ }^{46}$ That decision established this ownership through transfers based on adat (customary) law, which often do not require certificates.

The Court decided for the applicant and ordered the Medan Mayor to amend the Perda to include judicial decisions as a method of proof of entitlements to land. ${ }^{47}$ While the result is logical and might be expected (because it gives effect to an earlier Supreme Court decision), the legal reasoning was flawed: the Court identified neither a higher-level law with which the Perda conflicted, nor any other ground to support its holding.

The Supreme Court has resolved some Perda reviews by simply endorsing or rejecting policy contained in the Perda, again without referring to a higher-level law. So, for example, in the Jambi Coal Transportation case (2014), ${ }^{48}$ the applicants, two citizens, unsuccessfully challenged a Perda that required coal to be transported on special roads or by river after January 2014. They complained that these special roads either did not exist, were inappropriate for transporting large amounts of coal, or did not lead to port. They pointed to seven statutes and government regulations dealing with mineral and coal mining, regional government, and traffic. Although the Court acknowledged these as the bases for the applicants' claims, it did not address them in its decision, the entirety of which was as follows:

The high level of intensity of coal transportation through public roads in Jambi influences several aspects of the life of the community, whether social, cultural, or economic, or public security and order. Therefore, regulation of coal transportation activities is necessary.

The regulation was stipulated to regulate issues related to the use of particular public roads and rivers in the transportation of coal, and was seen to provide a just solution to the problems that arose concerning the high level of intensity of coal transportation. Therefore, it is hoped that various negative impacts can be avoided, both in the distribution of goods and services, the

\footnotetext{
44. Supreme Court Decision 31 P/HUM/2011, p. 11.

45. Supreme Court Decision $61 \mathrm{P} / \mathrm{HUM} / 2013$.

46. Supreme Court Decision 1040 K/Pdt/2012, pp. 20-1.

47. Supreme Court Decision 61 P/HUM/2013, pp. 17-18.

48. Supreme Court Decision 13 P/HUM/2014.
} 
transportation of people, and the safety of road users, and even the potential for conflict between the community and business operators.

At around the same time, the Court heard a similar challenge to the Batanghari County Regent Regulation on Coal Transportation (2014). ${ }^{49}$ This Regent Regulation was issued to implement the Perda disputed in the Jambi Coal Transportation case (2014) just mentioned. ${ }^{50}$ Here, the applicants were coal transporters and associated organizations, who complained that the Regent Regulation caused them loss because it prohibited them from using public roads to transport coal, and was discriminatory because operators in other industries were still permitted to use those roads. They pointed to several statutes that, they claimed, the Perda contradicted. Again, the Court's decision was very short and did not provide any legal reasons:

Mineral and coal resources are mining resources that are very important for the state, because they are an asset that can increase the income and reserves of the state.

As mineral and coal resources contained within the territory of Indonesia, these assets are nonrenewable riches that are a gift from Almighty God. Therefore, their management is controlled by the state so that they can provide clear added value to the national economy to achieve prosperity and welfare for the people.

Batanghari Regent Regulation 20 of 2013 on Coal Transportation Procedures was issued and brought into force as a regulation to implement Regional Regulation 13 of 2012 on the Regulation of the Transportation of Coal in the Province of Jambi.

The increasingly high level of intensity of coal transportation through public roads will influence aspects of life of the community, which, to ensure security and the public order, must be regulated.

The regulation was stipulated to regulate mining associations, individuals and others who engage in transportation of coal so that it is more ordered and better, and the income of the state through minerals and coal assets is increased further.

These cases sit uncomfortably alongside those where the Court has thrown out applications because the applicants did not identify the higher-level law that the Perda allegedly violated or specify how the impugned Perda conflicted with that higher-level law. For example, in the Jakarta Governor Regulation case (2009), ${ }^{51}$ several street traders challenged a Perda that allowed the Jakarta government to move them on from their places of business if those places were needed for the "purposes of the Jakarta administration." The Court found that the applicants had merely alleged that the Perda violated "applicable laws," without outlining the nature of the conflict. While the applicants had set out various statutory provisions, including from the Human Rights Law and the Law on Small-Medium Enterprises, they had not explained how the Perda violated them.

\subsection{Adequate Reasons, Limited Reasoning}

The reasons the Supreme Court gave in some decisions were sound, albeit short on detail and legal analysis. Most cases falling within this category appear to have been relatively straightforward, with the Court disposing of them by identifying the disputed provisions of the Perda and the provisions of the higher-level laws with which those Perda provisions conflicted,

49. Supreme Court Decision 14 P/HUM/2014.

50. Batanghari is a county of Jambi, which is a province located in Sumatra.

51. Supreme Court Decision 38 P/HUM/2009. 
and providing a description of the conflict, usually in two or three sentences. For example, in the Batang Regulation case (2013), ${ }^{52}$ a group of fishermen and farmers objected to a Perda that rezoned a coastal area as a "high technology area" to be used for construction of a power plant. ${ }^{53}$ The area had been designated as a natural ocean park under Appendix VIII, clause 313 of Government Regulation 26 of 2008. The Court held that there was no conflict, because the Perda referred to a land area, whereas the regulation applied to an ocean area.

Another example of adequate, though thin, reasons is the Sragen Officials case (2012). ${ }^{54}$ Here, the application was brought by ten village heads who complained about a Regent Regulation that limited their ability to appoint their own staff — an issue they claimed was already regulated by two higher-level laws: a Perda issued by the Sragen County Parliament $^{55}$ and national Government Regulation 72 of 2005 on Villages. The Court agreed, pointing to the relevant provisions of the regent regulation and the higher-level laws it contradicted. As the Court stated, the regent regulation required that, for appointment, village officials needed to be between 20 and 55 years old; but higher-level laws, including the County Perda that the regent regulation declared itself to implement, set the maximum age at $60 .^{56}$ The Court ordered the Regent to revoke the regulation. ${ }^{57}$

Another case in which the Supreme Court clearly identified a conflict between provisions of the impugned Perda and a higher-level law was the North Sulawesi Palm Oil case (2016) ${ }^{58}$ The applicant was a palm oil industry association that complained about how North Sulawesi Governor Regulation 12 of 2016 set the prices for fresh oil palm. The Court held for the applicants, finding that the price-setting formula in the Perda contradicted a formula contained in an Agriculture Ministry regulation. ${ }^{59}$

Finally, in the Gresik Parking case (2014), ${ }^{60}$ the applicants argued that a parking fee, which the impugned Perda required to be paid upfront when the car owner paid motor vehicle tax, was not a valid user charge (retribusi) as defined in Article 1(64) of the national 2009 Tax and User Charges Law. The Court agreed, noting that, under Article 1(64), retribusi was a fee for a specific service provided by a regional government to a person or an entity, based on the free will of the recipient of the service. By making the parking fee compulsory, the Perda violated this Law. ${ }^{61}$

\subsection{Reluctance}

As mentioned, the Supreme Court has refused to review some types of Perda, despite appearing to have jurisdiction. The Court has done this most conspicuously in cases involving highly political or particularly controversial issues.

52. Supreme Court Decision $44 \mathrm{P} / \mathrm{HUM} / 2013$.

53. Article 49 of Batang County Perda 7 of 2011.

54. Supreme Court Decision $41 \mathrm{P} / \mathrm{HUM} / 2012$.

55. Sragen County Regulation 15 of 2006 on the Village Apparatus.

56. Articles 26(3) and (4) of Government Regulation 72 of 2005 on Villages.

57. Supreme Court Decision 1 P/HUM/2012, p. 21.

58. Supreme Court Decision 4 P/HUM/2016.

59. 14/Permentan/OT.140/2/2013 on Guidelines for Setting the Price of Plantation-produced Fresh Oil Palm.

60. Supreme Court Decision $49 \mathrm{P} / \mathrm{HUM} / 2014$.

61. Supreme Court Decision 49 P/HUM/2014, pp. 13-14. 


\subsubsection{Waiting for Perda Invalidity?}

The Court has, in several cases studied, turned down challenges to Perda that were no longer in force by the time it came to decide those cases, even though those Perda were valid at the time the applicants sought review and for several months thereafter. ${ }^{62}$ Of course, the Court should not waste time and resources reviewing laws that are no longer valid. However, in these cases, the Supreme Court appears to have delayed its review of "time-limited" Perda that it knows will be revoked or replaced in due course, apparently as a strategy to avoid reviewing the Perda altogether.

For example, in the East Java Governor Regulation case (2015), ${ }^{63}$ the applicant, a business association, challenged a Perda establishing a minimum wage that, according to the applicant, had increased excessively since the previous year. The Court threw out the case, on the ground that the Perda in question had already been replaced by the time it had come to decide the matter. The impugned Perda was enacted on 20 November 2014 and the applicants had registered their case on 5 February 2015, about two and a half months later. However, when the Court decided the case, on 11 February 2016, the 2015 Perda had already been replaced, and a new minimum wage had been established by another Perda, enacted on 20 November 2015. The replacement of the impugned Perda was entirely to be expected, given that minimum wages must be revised at least every year. ${ }^{64}$ The Court would have known this, leaving the inevitable conclusion that it either put off the case to avoid deciding it, or paid no regard to the urgency of the application.

Similarly, in the Boyolali Perda case (2011), ${ }^{65}$ the Supreme Court was asked to review the legality of an annual regional budget, again established by Perda. The 2012 Boyali budget Perda was enacted on 31 December 2011 and the challenge to it registered on 2 February 2012. The 2012 budget was replaced with the 2013 budget on 31 December 2012, but the Supreme Court did not decide the case until 30 December 2013. As with the East Java Governor Regulation case (2015), the Court would have known at time of registration that the case was time-sensitive, given that budgets are replaced annually.

\subsubsection{Statute under Constitutional Review}

In another important category of cases, the Supreme Court has rejected applications because a statute the applicants claim the impugned Perda has violated was, itself, being reviewed in the Constitutional Court for consistency with the Constitution. To justify doing this, the Supreme Court has, in these cases, pointed to Article 55 of the Constitutional Court Law, which states:

The review of laws lower than statutes being conducted by the Supreme Court must be stopped if the statute that is the basis for the review is being reviewed by the Constitutional Court, until a Constitutional Court decision is made.

The Supreme Court will usually take this course upon formal notification by the Constitutional Court registrar that the relevant statute is under constitutional review. ${ }^{66}$

62. Supreme Court Decision $45 \mathrm{P} / \mathrm{HUM} / 2012$.

63. Supreme Court Decision $74 \mathrm{P} / \mathrm{HUM} / 2014$.

64. Articles 43 and 44 of Government Regulation 78 of 2015 on Wages and Articles 6-8 of Ministry of Manpower Regulation 7 of 2013 on the Minimum Wage.

65. Supreme Court Decision $17 \mathrm{P} / \mathrm{HUM} / 2012$.

66. See $17 \mathrm{P} / \mathrm{UM} / 2012$, p. 29. 
Four of the Supreme Court Perda review applications studied were rejected for this reason. In each case, the rejection appeared to be decisive of the review: none resumed after the constitutional challenge concluded. Yet, in all four cases, the applicants had argued that the Perda violated more than one statute, only one of which was under constitutional review in the Constitutional Court. Nevertheless, the Supreme Court dismissed each application in its entirety-rather than simply staying proceedings until the Constitutional Court cases had concluded. It thereby permanently avoided even the arguments in the application based on statutes not under review in the Constitutional Court.

So, for example, in the Boyolali Perda case $(2011),{ }^{67}$ the applicants argued that the impugned Perda contradicted the Regional Government Law (2004) ${ }^{68}$ and the Law-making Law (2011). ${ }^{69}$ The Supreme Court refused to hear the case because the Regional Government Law was under review in the Constitutional Court. The Court did not, therefore, consider the applicant's arguments that the Perda also violated the Law-making Law. Similarly, in the Ponorogo Perda case (2014), ${ }^{70}$ the applicants claimed that various Perda violated several statutes, including the 2014 State Civil Apparatus Law, ${ }^{71}$ which was under simultaneous constitutional challenge. ${ }^{72}$ Without considering the applicant's arguments based on other statutes, the Supreme Court declared the application "premature" and rejected it.

The Supreme Court has applied Article 55 to stop cases proceeding even in the face of strong arguments for the impugned Perda's invalidity. Two of the cases studied clearly demonstrate why this is undesirable. The first is the Dumai City Budget case (2014). ${ }^{73}$ The applicants argued that the Perda, which contained the Dumai city budget, violated the Regional Government Law, Law-making Law, and various lower-level national regulations. The Supreme Court refused to examine the case because the Constitutional Court was reviewing the Regional Government Law. However, the foci of the Supreme and Constitutional Court challenges were quite different. In the Supreme Court challenge, the applicants argued that the budget Perda violated Articles 65(2), 236(2), and 241(1) of the Regional Government Law, which require, in general terms, that Perda be debated and agreed to by both the regional head and the regional parliament. The Constitutional Court decision, on the other hand, concerned an entirely different provision-Article 158 of the Regional Government Law-which covered how parliaments are filled when a county or city splits into two. Because the cases and the parties involved in them were unrelated, and the cases were about different provisions of the same statutes, there seems no logical reason to prevent one case from proceeding while the other is on foot. The Supreme Court's blanket refusal to proceed brought to a curt end a case that raised fundamental law-making process questions and was undoubtedly time-consuming and costly for the applicant.

The second case brings the shortcomings of the Supreme Court's application of Article 55 into sharper relief. In 2014, the Aceh provincial legislature enacted Qanun Aceh 6 of 2014 on

67. Supreme Court Decision 17 P/HUM/2012.

68. Law 32 of 2004 on Regional Government.

69. Law 12 of 2011 on Law-making.

70. Supreme Court Decision 51 P/HUM/2014.

71. Law 5 of 2014 on the State Civil Apparatus.

72. Constitutional Court Decision 41/PUU-XII/2014.

73. Supreme Court Decision 83 P/HUM/2014. 
Islamic Criminal Law (Hukum Jinayat). ${ }^{74}$ This instrument significantly expanded the scope and application of Islamic criminal law in Aceh, including some of its punishments. ${ }^{75}$ The Qanun prohibits consumption and distribution of alcohol, gambling, "seclusion" (khalwatbeing alone in an enclosed or private place with a member of the opposite sex who is not a spouse or relative), and "intermingling" (ikhtilath - consensual intimate relations, such as flirting, touching, hugging, and kissing, between an unmarried male and female in a private or public area). It also prohibits adultery, sodomy, lesbian sex, sexual abuse, and rape. Punishments for these offences range from ten strokes of the cane, a fine of 100 grams of gold, or 10 months in prison for khalwat (Article 23(1)), to 150-200 strokes, 1,500-2,000 grams or 150-200 months for rape of a child or family member (Articles 49 and 50). ${ }^{76}$ The Qanun makes it particularly difficult for alleged victims to successfully pursue rape allegations, with alleged perpetrators able to escape a finding of guilt by declaring a willingness to face God's wrath if he or she is lying (Article 55). The Qanun also requires alleged victims to provide initial evidence of the rape and imposes punishments on them if the defendant is ultimately found not guilty. Article 72 stipulates that the Qanun Jinayat is the applicable law if an offence is regulated in both the Qanun Jinayat and the national Criminal Code (KUHP).

Unsurprisingly, the Qanun drew heavy criticism from gender and human rights activists in Indonesia and abroad, ${ }^{77}$ and the Institute for Criminal Justice Reform sought its judicial review before the Supreme Court. The application was comprehensive and well argued, and clearly pointed to provisions of higher-level laws that appeared to directly contradict, or at least not to support, the Qanun - particularly its use of caning as a punishment and its rules about proving rape cases. These higher-level laws included: the Criminal Code (which does not include caning as a permissible punishment in what appears to be an exhaustive list of punishments); the 1999 Human Rights Law and the International Covenant on Civil and Political Rights (which prohibit torture, including humiliating or inhumane punishments, into which caning appears to fall); and the Criminal Procedure Code (which requires police, not victims, to provide evidence of these crimes, and does not include an oath before God as a valid form of evidence).

The applicant also argued that the Qanun breached the 2011 Law-making Law in several ways. These included that the Qanun violated the "hierarchy of laws" in Article 7(1) of the Law-making Law because it conflicted with the higher laws already mentioned; duplicated national laws, which undermined legal order and certainty (thereby violating Article 6(1)(i) of the Law-making Law); and was unclear in its aims and use of legal terms and language, thereby creating multiple interpretations (Articles 5(a), (f), and 6(1)(g)).

The Supreme Court did not consider any of the applicant's arguments, deserving of attention though they were. The Court simply threw out the case, pointing to Article 55 of the

74. "Qanun" is an Arabic term for "law": see Esposito (2017). In Aceh, it is synonymous with the term "Perda" issued in other provinces: Aspinall (2006).

75. Aceh is the only province of Indonesia with power to issue laws based on Islamic norms; see Lindsey (2012). The Qanun applies primarily to Muslim individuals, but also to corporations conducting business in Aceh (Article 5) and, perhaps most controversially, to non-Muslims who commit offences proscribed in the Qanun Jinayat, but not national criminal law.

76. This description draws on Butt \& Lindsey, supra note 18.

77. See Kine (2017). 
Constitutional Court Law. This was because the Constitutional Court was examining the constitutionality of the 2011 Law-making Law. ${ }^{78}$ More specifically, the Constitutional Court was hearing a challenge to Article 7(1) of the Law-making Law-one of the provisions the applicants argued the Qanun violated.

To be sure, a strict reading of Article 55 seemed to require the Supreme Court to throw out the Qanun review. After all, both the Supreme Court and the Constitutional Court were considering the same provision-Article 7(1) of the Law-making Law. If the Constitutional Court invalidated Article 7(1) and the Supreme Court invalidated Qanun provisions for violation of Article 7(1), then much uncertainty and disputation would have undoubtedly resulted.

This potential problem was considered by the Constitutional Court itself in the Unlicensed Dentist case (2012). ${ }^{79}$ This was a constitutional challenge to Article 55 brought by a group of unlicensed dentists (tukang gigi) who had sought judicial review by the Supreme Court of a ministerial regulation that they claimed violated the national Health Law. Pointing to Article 55, the Supreme Court had refused to proceed with their application, because the Health Law was, at the time the Supreme Court was considering the case, being reviewed by the Constitutional Court in a separate case. The Constitutional Court refused to invalidate Article 55, holding that it was needed to prevent the legal chaos that would ensue if the Supreme Court invalidated a lower-level law for violating a statute that the Constitutional Court invalidated soon thereafter. Would this render the Supreme Court's decision invalid, or would it stand because it was made while the statute was still valid? According to the Constitutional Court, Article 55 is directed towards avoiding these types of questions and situations.

In my view, the Constitutional Court's justification for its decision-the avoidance of chaos and uncertainty - does not hold in cases where a Supreme Court judicial review application is based on two or more statutes, only one of which is under constitutional review. In such cases, the Supreme Court could stay the part of the application that refers to the statute under constitutional review but continue to hear the challenges to the remaining statute or statutes without jeopardizing Indonesia's legal order. After all, it would be open to applicants to lodge separate applications to challenge the validity of a lower-level law, alleging in each application that the lower-level law violated a different statute; they are heard as part of the same case for efficiency. Indeed, it is even arguable that the Constitutional Court's decision in Unlicensed Dentists should only apply to Supreme Court review cases involving one statute. The unlicensed dentists had, in their application before the Supreme Court, asked for review of a ministerial regulation against only one statute-the Health Law. ${ }^{80}$ The Constitutional Court was thus not asked to consider whether Article 55 should apply when the Supreme Court faces a judicial review case involving the alleged breach of multiple statutes. If the Supreme Court focuses only on arguments based on statutes not under constitutional review, no legal chaos or uncertainty can result, because the two courts will not be reviewing the same law.

78. Constitutional Court Decision 59/PUU-XIII/2015.

79. Constitutional Court Decision 74/PUU-X/2012.

80. As an aside, the challenge in the Constitutional Court to the Health Law, which had led the Supreme Court to reject the dentists' review application, was successful; see Constitutional Court Decision 40/PUU-X/2012. After this Constitutional Court decision was handed down, the applicants resubmitted their application against the ministerial regulation to the Supreme Court and were ultimately successful; see Supreme Court Decision 24 P/HUM/2012. 
Following this reasoning, in the Qanun Jinayat case, the Supreme Court could have "severed" arguments based on Article 7(1) of the Law-making Law, or even on the Lawmaking Law altogether, and continued to hear the case based on the Qanun's alleged violation of the other higher-level laws. After all, these alleged violations stood independently from the Law-making Law arguments. This way, there could have been no overlap between the Supreme Court and Constitutional Court cases and the Supreme Court could have addressed the serious legal problems with the Perda, including the apparent violation of fundamental rights, and its attempt to override the Criminal Code. It bears noting that, in any event, the parallel constitutional review of Article 7(1) of the Law-making Law proved to be no real obstacle. The Constitutional Court ultimately threw out the case for lack of standing, because the applicants established no clear constitutional ground to object to Article 7(1). ${ }^{81}$

\subsubsection{Standing}

Article $31 \mathrm{~A}(2)$ of the Supreme Court Law contains the Court's standing rules. ${ }^{82}$ It states: "An application ... can be brought only by parties who consider that their rights have been damaged by the operation of a law lower than a statute," that is:

1. an Indonesian citizen or class of citizens with the same interests ${ }^{83}$;

2. a customary law community, provided that it still exists and accords with community development and the principle of the Unitary Republic of Indonesia as regulated by statute; or

3. a public or private legal entity.

In effect, this provision imposes two main requirements: first, that the applicant or applicants fall within one of the categories mentioned in paragraphs (a)-(c); and, second, that the applicant or applicants identify a right that the impugned law violates. ${ }^{84}$

In a handful of cases studied, the Court did not strictly apply these requirements. For example, the Court has granted standing to citizens without providing any reason, ${ }^{85}$ and without clearly identifying any right or interest jeopardized or breached by the Perda being challenged. In some cases, it appears to have been enough that the applicants were, as the Court put it, "connected with the application of the Perda." ${ }^{86}$ For example, in the Mojokerto Bus Route case (2013), ${ }^{87}$ the applicants, who were mini-bus operators, drivers, and passengers, complained about a Perda that changed the bus route they used. In granting standing, the Court noted that the Perda would probably result in passengers needing to take an additional bus to reach their destinations and in bus operators enjoying less profit, but the case documentation set out no evidence of either. The Court also cited the right to

81. Constitutional Court Decision 59/PUU-XIII/2015, pp. 47-8.

82. Law 14 of 1985 on the Supreme Court as amended by Law 3 of 2009.

83. The "same interests" criterion is included in the Elucidation to this provision.

84. Effendi, supra note 5, p. 39. The rules do not seem to preclude an applicant or applicants from establishing standing based on violation of a right granted to them by one higher-level law and then, once standing is established, arguing that the impugned Perda or provisions should be invalidated for violating a different higher-level law.

85. Supreme Court Decision $38 \mathrm{P} / \mathrm{HUM} / 2009$.

86. Supreme Court Decision 05 P/HUM/2011.

87. Supreme Court Decision 26 P/HUM/2013. 
"take legal action concerning the guarantee of the fulfilment of the human rights of every citizen," but did not specify what human right was at stake in this case. ${ }^{88}$ In another case, standing was granted on the rather flimsy basis that the applicants "felt that their rights have been damaged because of the Perda," even though the applicants provided no evidence of direct damage, and argued merely that the Perda was enacted to serve political rather than community interests. ${ }^{89}$

The Court has taken a much stricter approach in comparable cases, opening itself to criticism that its decision-making about standing is inconsistent. In the Bogor County Perda case (2016), ${ }^{90}$ for example, the Court refused standing because the applicant did not "clearly outline a causal connection between his or her right and the law under review." 91 The Court made this finding even though the applicant was a citizen of the county and had argued that the Perda interfered with the management of water resources upon which the applicant relied. For the Court, it was insufficient that the applicant paid "intense attention" to issues of Bogor local government. ${ }^{92}$ Here, the Supreme Court ignored that the Constitutional Court has held, in separate proceedings, that citizens have a fundamental right to water. ${ }^{93}$ Similarly, the Supreme Court has, in several cases, rejected standing for failure to specify loss ${ }^{94}$ or a direct interest. ${ }^{95}$ Yet the Court did not require the specification of loss in the cases mentioned in the previous paragraph.

In another category of cases, the Court appears to have applied an additional standing requirement, imposed neither by the Supreme Court Law nor by the 2011 Supreme Court Regulation on Judicial Review: "residency" within the territorial jurisdiction of the Perdamaker. In one case, for example, applicants were not granted standing to review a South Tangerang City Mayor Regulation because they were not residents of South Tangerang. ${ }^{96}$ (They lived in another city of Tangerang.) In another case, discussed below, applicants complained about a Perda that specified the design of the Aceh provincial flag. The Court denied standing because the applicants had not provided identity cards proving that they were Indonesian citizens, let alone residents of Aceh. ${ }^{97}$ In yet another case, a potential investor sought review of a Perda issued by the Brebes legislature that established a local spatial plan. ${ }^{98}$ The Court rejected the application for lack of standing because the applicant, a corporation, was not domiciled in Brebes and had not yet begun investment activities there. Yet, the applicant clearly did have an interest in the impugned Perda, having built a $24,000 \mathrm{~m}^{2}$ garment factory without permission, in a location allocated under the Perda for wetland farming. The local government had closed the factory based on that Perda. ${ }^{99}$

88. Supreme Court Decision $26 \mathrm{P} / \mathrm{HUM} / 2013$, p. 32.
89. Supreme Court Decision $45 \mathrm{P} / \mathrm{HUM} / 2011$.
90. Supreme Court Decision $13 \mathrm{P} / \mathrm{HUM} / 2016$.
91. Supreme Court Decision $13 \mathrm{P} / \mathrm{HUM} / 2016$, p. 29.
92. Supreme Court Decision $13 \mathrm{P} / \mathrm{HUM} / 2016$, p. 29.
93. Constitutional Court Decision $85 / \mathrm{PUU}-\mathrm{XI} / 2013$.
94. Supreme Court Decision $02 \mathrm{P} / \mathrm{HUM} / 2012$.
95. Supreme Court Decision $15 \mathrm{P} / \mathrm{HUM} / 2013$.
96. Supreme Court Decision $39 \mathrm{P} / \mathrm{HUM} / 2009$.
97. Supreme Court Decision $47 \mathrm{P} / \mathrm{HUM} / 2016$.
98. Supreme Court Decision $76 \mathrm{P} / \mathrm{HUM} / 2014$.
99. Hendrik (2014). To be fair, the company did not, in the documents it submitted, mention that it had built this
factory, arguing only that the Perda impeded investment. Presumably, the company did not want to incinate 
This case demonstrates that residency really should not be a prerequisite for standing. The only question should be whether the applicants are sufficiently affected by the Perda because they or their interests are located within the jurisdictional reach of the local government. Permanent or long-term location there might make being affected more likely, but it is not determinative.

The Supreme Court also appears to have established a rule precluding annual budgets of subnational governments from review. In the cases studied where Perda containing these budgets were challenged, the Court generally refused standing. In the East Java Provincial Budget case (2014), for example, the Supreme Court held that a group cannot challenge a Perda that establishes a regional budget, because that Perda does not apply generally to the public, but rather only to the government when it allocates funds. ${ }^{100}$ This approach is problematical, given that subnational budget guidelines are often contained in national legislation on health, education, and national development. ${ }^{101}$ Surely, those affected by the way a local government has allocated funds should be able to keep that local government to national standards.

Of course, courts the world over are subject to standing rules that limit the availability of judicial review. However, these cases seem to indicate that the Court's approach to standing, albeit inconsistent, unduly restricts litigants, who have a legitimate interest in challenging the legal validity of generally applicable laws that affect them and their community. The additional requirements the Court appears to have added support this impression. It is, however, difficult to conclude that the Court's approach to standing provides further evidence of the Supreme Court's general reluctance to perform its judicial review function. This is because, as mentioned, the Court appears to have been quite lenient about standing in some cases.

\subsection{Deference to Government}

In several cases, the Court has rejected Perda review applications, apparently in deference to a government official or institution of a higher-level than the maker of the Perda under review, such as the national government or provincial governor. By contrast, in other cases, the Court appears to have deferred to the maker of the Perda, giving very little, if any, weight to applicant arguments once the Court established the jurisdiction of the Perda-maker. Both categories of cases appear to indicate a reluctance to become embroiled in sensitive political issues, even if the dispute is relatively straightforward from a legal perspective.

\subsubsection{Deference to a Higher Level of Government}

For example, in the Semarang Spatial Plan case (2012), ${ }^{102}$ the applicants complained about a Perda that rezoned the land upon which their company offices were built to non-commercial use. The Court rejected their application, concluding that the Perda had breached no higher-level laws. However, the Court did not consider the Perda by reference to any of the laws the applicant claimed it contradicted, merely pointing out that the Central Java Governor had reviewed and approved it, and that it accorded with national and subnational spatial plans. Problematically, the Court did not demonstrate in its reasons that it

100. Supreme Court Decision 74 P/HUM/2014.

101. Supreme Court Decision $47 \mathrm{P} / \mathrm{HUM} / 2014$.

102. Supreme Court Decision $52 \mathrm{P} / \mathrm{HUM} / 2012$. 
had independently assessed the legality of the impugned Perda. Surely, the Court must test the arguments put before it rather than simply relying on the governor's approval.

The Court took a similar approach in the Bandung Spatial Plan case (2011). ${ }^{103}$ Various businesspeople claimed that the plan was enacted only to serve political interests and would adversely affect the livelihoods of 4,000 workers and their families. They also alleged that the Perda violated the Constitution and several statutes. The Court refused to consider their arguments, holding simply that the Perda containing the plan had "definitely" already been subject to "technical and legal scrutiny" and "synchronised with related laws," including the central and regional spatial plans, and environmental rules. ${ }^{104}$ Again, the Court provided no further explanation or evidence indicating that it had independently considered whether the Perda violated higher-level laws.

\subsubsection{Deference to the Perda-Maker}

As mentioned, the Supreme Court has rejected applications after finding that the general subject matter of the Perda falls within the regional government's jurisdiction. Some of these cases are problematical because the Court has ignored important legal issues when establishing jurisdiction and because, once the Court has established jurisdiction under one law, it has sometimes ignored other laws restricting how that jurisdiction is to be exercised.

An example of the Court establishing jurisdiction but then ignoring the effect of other laws on that jurisdiction is the Jakarta Parking case (2012). ${ }^{105}$ This case was brought by lawyer David Tobing, who challenged the legality of a Perda that placed responsibility for loss or damage to a car left with paid parking attendants upon the owner of the car, rather than the attendants. The lawyer claimed that this violated Article 18(1)(d) of the 1999 Consumer Law, which states that "Business operators offering goods and/or services for trade are prohibited from making or including a standard clause in any document and/or contract if ... it declares the transfer of responsibility of the business operator."

Tobing also pointed to several cases in which the Supreme Court had held that parking management was responsible for losses, not the owner of the car using the parking services. For its part, the respondent pointed out that a new law had been enacted, which imposed liability upon insurers.

The Court's decision did not respond to any of Tobing's arguments. Rather, it simply held that there was no conflict between the Perda and Article 18(1)(d) because various higherlevel laws permitted local governments to impose parking fees. The Court seemed content to accept that establishing that the local government had jurisdiction to issue a Perda imposing parking fees disposed of the argument that the Perda violated the Consumer Law. Of course, these are two separate questions, but the Court conflated them. A Perda can be invalid, first, if the local government lacked jurisdiction to enact it or, second, if it conflicts with a higher law. In this case, the Court could easily have found that the local government had jurisdiction and that there was no conflict. In any event, the applicant's arguments about standard-form contracts were clearly spurious, given that standard clauses, as defined in the Consumer Law, appear in contracts or agreements, not laws, which apply generally to all.

103. Supreme Court Decision $45 \mathrm{P} / \mathrm{HUM} / 2011$.

104. Supreme Court Decision 45 P/HUM/2011, p. 46. The Court stated that the main remedy for the applicants was compensation.

105. Supreme Court Decision 30 P/HUM/2012. 
The Kudus Karaoke Perda case (2016) provides another example of the Court upholding a Perda after establishing that the local government had jurisdictional authority to issue it, without considering the effect of other relevant laws. ${ }^{106}$ The applicant, the head of the Indonesia-wide Association of Restaurant and Karaoke Entertainment Operators (ASPREHIKAS) ${ }^{107}$ challenged the impugned Perda's requirement that karaoke be provided only in five-star hotels, not other establishments. Article 4 also prohibited the provision of in-room karaoke, alcohol, dancers, and other services during Ramadan (the Islamic fasting month) or after 11 p.m. The applicants argued that this violated several higher-level laws, including laws on tourism.

The Court rejected the application, holding that regulating discos, night clubs, pubs, and karaoke establishments fell within the jurisdiction of regional governments. The Court mentioned the 2009 National Tourism Law but declared simply that the Perda did not violate it, without explaining why. The Court stated:

in order to create order in the community through the guarantee of Legal Certainty the local government needed to create policy in the regulation [of these issues] keeping in mind sociological values - that is, that the people of Kudus are religious ... and already accord with moral values that have developed in the community as a Santri ${ }^{108}$ City. Therefore, there is no conflict ... either in terms of jurisdiction or in the content of the regulation .... The respondent has jurisdiction to regulate, limit, and prohibit [those activities] in accordance with religious values, morals, ethics and local custom, which are not necessary the same as in other regions (see Articles 236(4) of the [2014 Regional Government Law]). ${ }^{109}$

The Court did not then consider any of the arguments put forward by the applicants about higher-level laws that might have affected the exercise of the local government's jurisdiction. Rather, the Court merely stated that the local government had jurisdiction to regulate these areas, and an interest in doing so.

It seems clear from the above passage from the Kudus Karaoke Perda case (2016) that the Court found that the impugned Perda reflects religious values. The Court has heard several challenges to Perda that either specifically refer to a religion or reflect the recognized religious norms of a religion-usually Islam-including those seeking to restrict or prohibit the consumption, sale, or distribution of alcoholic beverages during the holy month of Ramadhan and/or the holy days of Idul Fitri and Idul Adha. ${ }^{110}$ For example, the Perda reviewed in the Kuningan Alcoholic Beverages case $(2014)^{111}$ banned the production, sale, and consumption of alcohol entirely, citing reasons of order, community health, religion, and morality. Another example is Surabaya Perda 23 of 2012 on Tourism, which was challenged in 2013. ${ }^{112}$ While not concerned with alcohol per se, it prohibited night clubs, massage parlours, most karaoke bars, spas, and pubs from opening during Ramadhan, Idul Fitri and Idul Adha (Article 24(1)). The Elucidation to Article 24(1) explains

106. Supreme Court Decision 06 P/HUM/2016.

107. Asosiasi Pengusaha Restoran dan Hiburan Karaoke Kudus.

108. 'Santri' is a term commonly used to describe devout Muslims.

109. Supreme Court Decision 06 P/HUM/2016, p. 70. Article 236(4), of the Regional Government Law states that "Perda can contain local content, in accordance with the law."

110. Supreme Court Decision 09 P/HUM/2010.

111. Supreme Court Decision 64 P/HUM/2014.

112. Supreme Court Decision 34 P/HUM/2013. 
that the provision is intended to "respect the Muslim community" who engage in those activities. $^{113}$

These cases raise important jurisdictional questions because, as mentioned, religion falls within the exclusive jurisdiction of the national government. Some commentators have suggested that Perda such as these could be classified as matters of "public order," which do fall within the jurisdiction of lower-level governments. ${ }^{114}$ However, the Supreme Court has not engaged in this debate. In none of these cases has the Court considered arguments about how these Perda should be classified, even though this issue seems central to determining whether the local government does, in fact, have jurisdiction to enact religion-related Perda. The Supreme Court might have considered whether the references to religious fasting months, or holidays, or in Surabaya, "respect for the Muslim community," indicates that these Perda fall outside of local government jurisdiction, because they are really about religion.

The Court's failure to enter such debates is arguably an indication of its apparent general unwillingness to become embroiled in sensitive disputes that may have political ramifications or subject it to criticism and protest. Perhaps the high-water mark of the Supreme Court's avoidance of these types of disputes is the Aceh Flag case (2017), ${ }^{115}$ discussed earlier in the context of standing. This was a review of a Qanun that established the Aceh logo and flag and adopted the banner of the Free Aceh Movement (Gerakan Aceh Merdeka, or GAM). This entity struggled for decades against the central government, and its military, in a bloody civil war for independence from Indonesia, before Special Autonomy was negotiated between Aceh leaders in exile and representatives of the Indonesian government. GAM is not mentioned in the Qanun, but its flag appears to be accurately described in Article 4 , which outlines the dimensions, shapes, and colours to be used as the logo and flag of Aceh. ${ }^{116}$

As discussed, the Supreme Court refused to grant standing to the applicants, who had not proved their status as citizens of Indonesia or residents of Aceh. The Court provided one further reason:

The evidence produced by [one of the respondents] indicates that this issue is a very sensitive political issue, and so it would be better if its resolution involved an active role of the central government, or through executive review by the Ministry of Home Affairs. ${ }^{117}$

In other words, the Court refused to become embroiled in what was, in its view, a political problem rather than a legal one. However, this case had a clear legal resolution because a higher-level law clearly forbids the Perda adopting that flag. Article 6(4) of Government Regulation 77 of 2007 on Regional Symbols prohibits regional logo designs and flags from being the same as or like the logo design or flag of a separatist movement in Indonesia. Article 6(4) clearly applies to the GAM flag, because the Elucidation to that provision states "what is intended by logo designs and flags of prohibited organisation or separatist ...

113. While the Court found that the applicants—owners or operators or such establishments—had standing, it decided that they had not specified provisions of the national tourism statute that contradicted the Perda.

114. Parsons and Mietzner, supra note 3.

115. Supreme Court Decision 47 P/HUM/2016.

116. Anggara (2013); Cochrane (2013).

117. Supreme Court Decision 47 P/HUM/2016, p. 32. 
movements in this provision is, for example, the logo and flag of the crescent moon used by separatist in Aceh."

The law and its application were straightforward. The Court should simply have compared the logo as outlined in the Qanun, with the GAM logo and flag. If it deemed them to be similar or the same, it should then have invalidated the Qanun's adoption of the flag.

\section{CONCLUSIONS}

The cases studied here clearly demonstrate that, overall, Indonesia's Supreme Court is performing its judicial review function poorly. This will not be surprising to most Indonesia observers: almost all Indonesian courts, including the Supreme Court, have long been criticized for poor decision-making and integrity in their criminal-, civil-, and administrative-law cases. ${ }^{118}$ However, as the Supreme Court has begun hearing more judicial review cases in the past decade or so, its decisions in them, described above, have opened it up to new criticisms. This is at least partly because the Supreme Court's function in these judicial review cases is very similar to that performed by the Constitutional Court in constitutional review cases- to check the exercise of law-making power by government. The decisions of both courts attract significant media attention. It is, therefore, difficult to avoid comparing the relative performance of these two courts in the review cases they handle.

The main difference between their review powers is that, as mentioned, the Constitutional Court reviews the constitutionality of statutes, whereas the Supreme Court assesses the validity of lowerlevel laws - either against statutes or "higher-level" laws, but not against the Constitution. While scholars regard the Constitutional Court's review function as particularly significant, the importance of the Supreme Court's review function is often underemphasized; but its function is at least as important as, if not more important than, the Constitutional Court's. Just like the Constitutional Court, the Supreme Court has power to invalidate laws that violate the fundamental human rights of citizens and that allow the government to avoid its legal obligations. This is because all the rights and many of the obligations contained in Indonesia's Constitution are echoed in statutes and other lower-level laws. ${ }^{119}$ But the Supreme Court's review power extends to a much wider category and number of laws, most of which do not draw the same levels of public and media scrutiny as national legislation, which the Constitutional Court reviews. Many of the laws the Supreme Court can review need only be signed into law by a government official—such as the president or a minister — or are passed by regional legislative assemblies, the deliberations of which are often not widely reported, if at all. ${ }^{120}$ Given this potential for less transparency and public scrutiny, these laws arguably have more potential to impede the rights of citizens than does national legislation. If complaints about predatory and discriminatory bylaws are anything to go by, ${ }^{121}$ the need for effective Supreme Court review is particularly pressing. This need is now even more acute because, by virtue of the 2017 Constitutional Court decisions mentioned at the outset, the Supreme Court is now the only institution that can review and invalidate most types of regional laws.

118. Pompe, supra note 2; Butt \& Schutte (2014); Aspandi, supra note 2.

119. For example, the rights contained in Indonesia's constitutional "Bill of Rights" reproduce in large part the vast catalogue of rights provided under Law 39 of 1999 on Human Rights.

120. See Butt \& Lindsey, supra note 18, Chapter 2.

121. Amindoni (2016); Muhyiddin (2014). 
This similarity in review functions invites comparisons that are far more flattering for the Constitutional Court than the Supreme Court. Soon after the Constitutional Court's establishment in 2003, commentators and scholars began seeing it as a model for judicial reform in Indonesia, particularly because of the way it handled and decided its constitutional review cases. To be sure, many of the Constitutional Court's decisions can be criticized for having unexpected findings or insufficient legal analysis. And, like judges working in other Indonesian courts, some Constitutional Court judges have been convicted for accepting bribes to fix the outcome of cases. Despite these problems, the Constitutional Court's decision-making practices remain clearly superior to the Supreme Court's in judicial review cases in three main areas. First, the Constitutional Court's judgments are much longer and more discursive than the Supreme Court's, and they usually provide relatively detailed explanations about how the Court reached its decisions, even if these explanations are not always convincing. ${ }^{122}$ This appears to indicate that the Constitutional Court is at least aware of the need to be transparent and accountable for its decisions. Second, despite apparently being initially reluctant to cite its own prior decisions, the Court now routinely quotes from them, apparently exhibiting a concern to maintain consistency in its decision-making. This appears to be part of the Constitutional Court's attempts to develop the body of constitutional jurisprudence that Indonesia has always lacked. ${ }^{123}$ Third, the Constitutional Court has neither shied away from highly political or controversial cases nor avoided finding against the government, often invaliding statutory provisions and even entire statutes. To these three areas can be added another advance that supports the Court's apparent concern to maintain transparency, accountability, and consistency: decision publication. The Constitutional Court has always made its decisions readily accessible, uploading them to its website almost immediately after they are read out in open court. Scholars and lawyers have, therefore, been able to obtain sufficient material to "engage" with the jurisprudence the Court has been developing - that is, to identify it, critique it, and suggest how the Court might progress it. ${ }^{124}$

As is clear from the preceding case analyses, the Supreme Court's decision-making in these cases is defective in all three areas for which the Constitutional Court has been applauded. Its decisions contain no or inadequate reasoning and are often inconsistent, and the Court appears to be very quick to avoid hearing cases, especially when they are highly political. As this article demonstrates, this makes it possible only to identify general trends in the Supreme Court's decision-making. It is very difficult to identify Supreme Court review jurisprudence-if it exists—let alone "engage" with it. Why, then, are the decision-making standards and processes of these two courts in these three areas so dramatically different, even though their functions are so similar?

\subsection{Reasoning}

The Supreme Court's failure to provide legally comprehensive and comprehensible reasoning in its decisions has been long lamented. As mentioned, this problem is not unique to its judicial review cases, but rather has been observed in most, if not all, categories of cases

122. Butt (2007).

123. Butt \& Lindsey, supra note 11 .

124. See Butt, supra note 122; Hendrianto, supra note 12; Stockmann (2007); Butt \& Lindsey, supra note 11; Butt, supra note 12 . 
it decides. Several factors are said to contribute to the problem. One is that judges spend insufficient time considering their cases and writing their judgments, because of the Supreme Court's case-load and mammoth administrative responsibilities. The Court's case-load is immense, with somewhere between 10,000 and 15,000 new cases being lodged with it each year, and the Court having only 40 to 50 judges at any given time to handle them. ${ }^{125}$ The Court has whittled down a massive backlog over the past decade or two, and generally disposes of most cases within a year. However, this achievement must have been the result of judges spending less time deciding each case, which cannot have had a positive effect on judgment quality. The Court's non-judicial responsibilities have also increased markedly over roughly the same period. Under the post-Soeharto satu atap reforms mentioned above, the Supreme Court assumed control over the administrative and financial affairs of the lower courts and the 45,000 officials and 10,000 or so judges who work there. These matters had previously comprised the bulk of the workload of an entire government department- the Ministry of Justice. ${ }^{126}$ Some commentators have claimed that these reforms have distracted judges from their core adjudicative functions and have tied these increased administrative responsibilities to a steady decline in Supreme Court judgment quality over past decades. ${ }^{127}$ By contrast, the Constitutional Court's nine judges handle between 100 and 150 cases per year.

Another explanation may lie in the lingering effects of the civil-law tradition, which Indonesia inherited from the Dutch. Historically, some courts in civil-law countries have preferred to write very short judgments that are designed to appear to reach inevitable conclusions, without consideration of alternative arguments. ${ }^{128}$ However, this explanation should be accorded very little, if any, weight in today's Indonesia. Many civil-law countries today employ much more discursive judgment styles and, in Indonesia, the Constitutional Court has demonstrated that Indonesia's legal tradition does not prevent judgments from containing extensive reasoning.

Yet another possible reason is the influence of corruption, which is said to be rampant in the Court, ${ }^{129}$ and may account for decisions that appear primarily concerned with reaching a result rather than explaining how that result was reached. Even if corruption was not a factor in the judicial review cases discussed above, Supreme Court judges might be so accustomed to fixing outcomes that they may have lost sight of the importance of legal argument and providing solid reasoning. ${ }^{130}$

Finally, the Court's lack of technical or legal capacity and experience in handling judicial review cases is likely a relevant factor, even though the Court has had its judicial review powers for some decades. Most Supreme Court judges are so-called "career" judges, who have made their way up the judicial hierarchy later in their careers to the Supreme Court, having no experience in judicial review cases until they reach that Court. (This is because Indonesia's lower-level courts lack review jurisdiction.) Again, this factor should not be accorded undue weight, because the Supreme Court's reasoning is often problematic in types

\footnotetext{
125. Mahkamah Agung (2017), p. 24.

126. Butt \& Lindsey, supra note 18.

127. Hukumonline (2010).

128. Bell (1997); Lasser (2004); Wells (1994).

129. Butt \& Lindsey, supra note 2; Wulandari (2010).

130. See Pemberton (1999); Assegaf (2002); ICW (2001).
} 
of non-review cases that the Court has always handled. Further, the Court's experience in judicial review has undoubtedly increased over the past decade or more since it has begun hearing more review cases.

\subsection{Inconsistencies and Jurisprudence}

As described above, some of the Court's review decisions are blatantly inconsistent with others, even in respect of fundamental matters such as standing and the Court's jurisdiction. Again, this problem is not unique to judicial review cases and it raises questions about the Court's practical concern to maintain consistency in the application of the law-one of the main tasks of a court of cassation. ${ }^{131}$ Of course, like other civil-law countries, Indonesia does not have a formal system of precedent, but it has long been acknowledged that judges should follow previous decisions where possible in the interests of legal certainty and predictability. ${ }^{132}$ One Supreme Court judge has even described Indonesia as having a de facto system of precedent. ${ }^{133}$

Nevertheless, it has long been difficult for Indonesian judges to follow previous decisions, for two main reasons. First, most prior decisions have not been accessible, even for judges. A small fraction of Supreme Court judgments was published annually for several decades after independence, but these were selected on an ad hoc-sometimes seemingly randombasis. ${ }^{134}$ However, since Soeharto's fall, many more Supreme Court decisions have been made available, through the publication of various non-governmental organization (NGO) collections (most notably, "hukumonline" (www.hukumonline.com)) and, from 2007, the Supreme Court itself on its website (putusan.mahkamahagung.go.id). In the intervening decade or so, the Court claims to have uploaded almost 100,000 Supreme Court judgments, and almost 2 million judgments from other Indonesian courts. ${ }^{135}$ However, many of the Court's website entries contain "dead links" and judgments are usually not released immediately after being handed down. Also, a good portion of the Court's judgments have not been published at all, leading some reformers to fear that the Supreme Court is reluctant to release controversial decisions. ${ }^{136}$ Of course, this criticism cannot be made of the Constitutional Court, which publicly releases all its decisions-and even transcripts of trial proceedings. To be fair, the Constitutional Court's case-load is comparably miniscule, and uploading all Supreme Court decisions is a much more onerous task.

Second, even if a relevant prior decision can be located, its utility will be questionable if it contains insufficient legal reasoning to enable a subsequent court to follow it. In particular, it will be difficult to follow a decision that does not outline the relevant law or how the court applied it. These shortcomings mar almost every Supreme Court decision covered in this

131. Geeroms (2002), p. 211.

132. See BPHN (1993).

133. Lotulung (1997); see also Supreme Court Circular Letter 2 of 1972, which states that Supreme Court compilations of yurisprudensi "must be followed by judges when deciding cases."

134. Pompe, supra note 2.

135. Mahkamah Agung, supra note 22, p. 85.

136. Indeed, some more controversial decisions - about which there is significant negative publicity and public reaction-have never appeared online. For example, a 2007 Supreme Court decision (16 P/Hum/2006) upholding the legality of a controversial 2005 regional regulation of the Tangerang city government banning suspected prostitution has, to my knowledge, never been formally published by the Supreme Court. Rather, it was reproduced in Kamil \& Bamualim (2007). 
research and are very commonly found in Supreme Court judgments concerning other areas of law. Indonesian legal research is now often a matter of sifting through piles of decisions that have been roughly categorized on the Supreme Court's website, most of which contain little or no reasoning and do not outline their contribution to the development of the law. Again, the civil-law tradition is often blamed for this, but such criticisms are misplaced because many courts in countries following that tradition-and, indeed, Indonesia's Constitutional Court—now engage in a fuller discussion of prior cases and their relevance than Indonesia's Supreme Court. In short, even though many Supreme Court decisions are now available, there is often little utility in obtaining and reading them. Unlike those of the Constitutional Court, the Supreme Court's decisions simply do not appear to be written with readability in mind.

This historic lack of access to judgments, even for judges, and their general lack of usefulness have led to the following situation, as described by Bedner:

judges have become unaccustomed to reading and understanding precedents, which has inevitably led to a decline of legal consistency. Only when judgments get much attention in the media are they potentially taken into account in future cases. This has led judges to a singular reliance on legislation, which in turn has caused them to be often accused of an excessively formalist attitude. It also means that the Supreme Court has lost much of its ability to control legal development in Indonesia. Still, the effects on the nature and quality of judicial reasoning are even more serious. "Doing law" for Indonesian judges means looking at the facts of the case and applying usually broad, general statutory rules to them. This means that judges have to reinvent the wheel from one case to the other and produce quite diverse decisions in similar cases. ${ }^{137}$

\subsection{Deference and Reluctance}

The Supreme Court's apparent reluctant to hear or to consider review cases on their merits seems to indicate an unwillingness or inability to act as an independent check on the exercise of government power. Here, I do not mean to infer that the Supreme Court is dependent on government; I found no evidence of this. Rather, it appears that the Court simply prefers to avoid exercising its powers of judicial review whenever possible.

The reasons for this are unclear. Indonesian courts are said to be particularly sensitive to public opinion, ${ }^{138}$ and it is possible to speculate that some Supreme Court judges believe that disturbing the regulatory status quo is more likely to draw criticism than simply doing nothing, even in the face of apparently egregious laws under review. It is possible, too, that some judges are simply uncomfortable with intervening in the highly fraught politics of regional government and law-making. After all, these review cases are really "new disputes," in which the state, represented by the central government and a regional government, is "in essence, fighting itself." 139 Of course, during the Soeharto regime, the Supreme Court was expected to uphold the interests of the regime in it decisions. But the precise locus of political power in Indonesia today has become unclear, even arguably to the courts. The Indonesian "state" is "no longer synonymous with the Indonesian presidency, or even the national government .... Even if the Court were inclined to side with the 'government' it is now unclear which institution or tier of government it would side with." 140

137. Bedner (2013), pp. 256-7.

138. World Bank (2004); Cochrane (2017).

139. Butt \& Parsons, supra note 3, p. 58, emphasis in original.

140. Ibid., p. 59. 
While it might be presumed that, because the Supreme Court is a national institution it will naturally tend to side with the national government, this is not borne out in the cases discussed in this article. It also bears noting that deference and reluctance were evident in some, but not all, cases. This might reflect differences of opinion and approach among Supreme Court judges about the extent to which it is proper for courts to intervene in political matters. ${ }^{141}$ It also underlines the inconsistency that plagues the Supreme Court's decisionmaking. The question now is whether the Supreme Court will retain jurisdiction to review Perda and other lower-level laws for much longer, particularly if an increased judicial review workload attracts greater scrutiny of its flawed decision-making. Many Indonesian lawyers are already calling for the Constitutional Court to take over this function. ${ }^{142}$ It is ironic, then, that the Constitutional Court, which handed the Supreme Court exclusive jurisdiction to review Perda without paying due regard to the Supreme Court's track record in review cases, might ultimately come to exercise that jurisdiction itself.

\section{REFERENCES}

ADB (2005) Capacity Building to Support Decentralization in Indonesia, Jakarta: Asian Development Bank.

Ahmad, Ehtisham, \& Ali Mansoor (2002) "Indonesia: Managing Decentralization." Working Paper, 136 International Monetary Fund 1-20.

Ahmad, Junaid, Shantayanan Devarajan, Stuti Khemani, \& Shekhar Shah (2005) "Decentralization and Service Delivery.” World Bank Policy Research Working Paper 3603, The World Bank, 1-27.

Almanaf, Rival (2017) "Perda Perangkat Desa Demak Beda Dengan Pemerintah, Ini Tanggapan DPRD." Jateng News, 8 August.

Amindoni, Ayomi (2016) "Government Annuls 3,143 Bylaws." Jakara Post, 13 June.

Anggara (2013) "Bendera Dan Lambang Aceh: Problem Hukum Yang Tersisa." Hukumonline, 2 April. Arnold, Luke Lazarus (2009) "Acting Locally, Thinking Globally? The Relationship between Decentralization in Indonesia and International Human Rights." 2 Journal of East Asia and International Law 177-203.

Aspandi, Ali (2002) Menggugat Sistem Hukum Peradilan Indonesia Yang Penuh Ketidakpastian, Surabaya: Lembaga Kajian Strategis Hukum Indonesia dan Lutfansah Mediatama.

Aspinall, Edward (2006) The Helsinki Agreement: A More Promising Basis for Peace in Aceh?, Washington, DC: East-West Center Washington.

Assegaf, Ibrahim (2002) "Legends of the Fall: An Institutional Analysis of Indonesian Law Enforcement Agencies Combating Corruption," in T. Lindsey \& H. W. Dick, eds., Corruption in Asia: Rethinking the Governance Paradigm, Annandale: Federation Press, 127-46.

Asshiddiqie, Jimly (2008) Menuju Negara Hukum Yang Demokratis, Jakarta: Sekretariat Jenderal dan Kepaniteraan Mahkamah Konsititusi.

Aziz, Noor M. (2010) Laporan Akhir Pengkajian Hukum Tentang Eksistensi Peraturan PerundangUndangan Di Luar Hierarki Berdasarkan UU No.10 Tahun 2004 Tentang Pembentukan Peraturan Perundang-Undangan, Jakarta: Badan Pembinaan Hukum Nasional Departemen Kehakiman.

Barr, Christopher M. (2006) Decentralization of Forest Administration in Indonesia: Implications for Forest Sustainability, Economic Development, and Community Livelihoods, Bogor: Center for International Forestry Research.

Bedner, Adriaan (2010) "Consequences of Decentralization: Environmental Impact Assessment and Water Pollution Control in Indonesia." 32 Law \& Policy 38-60.

141. Many Supreme Court judges, including Chief Justices, acknowledge that judges can hold different opinions from each other, and that it is legitimate for this to be reflected in their decision-making. See Butt (2014).

142. Saputra (2017). 
Bedner, Adriaan (2013) "Indonesian Legal Scholarship and Jurisprudence as an Obstacle for Transplanting Legal Institutions." 5 Hague Journal on the Rule of Law 253-73.

Bell, John (1997) "Comparing Precedent." 82 Cornell Law Review 1243.

Bird, Richard M. (2007) Fiscal Fragmentation in Decentralized Countries: Subsidiarity, Solidarity and Asymmetry, Cheltenham: Edward Elgar Publishing.

BPHN (1993) Laporan Penelitian Tentang Peningkatan Yurisprudensi Sebagai Sumber Hukum. Jakarta: Badan Pembinaan Hukum Nasional, Departemen Kehakiman.

Butt, Simon (2007) "Judicial Review in Indonesia: Between Civil Law and Accountability? A Study of Constitutional Court Decisions 2003-2005." PhD diss., Law Faculty Melbourne University.

Butt, Simon (2008) "Surat Sakti: The Decline of the Authority of Judicial Decisions in Indonesia," in T. Lindsey, ed., Indonesia: Law and Society, Annandale, NSW: Federation Press, 346-58.

Butt, Simon (2010) "Regional Autonomy and the Proliferation of Perda in Indonesia: An Assessment of Bureaucratic and Judicial Review Mechanisms." 32 Sydney Law Review 177.

Butt, Simon (2014) "Judicial Responses to the Death Penalty in Indonesia." 39 Alternative Law Journal 134-35.

Butt, Simon (2015) The Constitutional Court and Democracy in Indonesia, Leiden: Brill.

Butt, Simon (2018) "The Indonesian Constitutional Court and Regional Autonomy: Reconfiguring Decentralisation for Better or Worse?" Asian Journal of Comparative Law (forthcoming).

Butt, Simon, \& Tim Lindsey (2010) "Judicial Mafia: The Courts and State Illegality in Indonesia," in G. Van Klinken \& E. Aspinall, eds., The State and Illegality in Indonesia, Leiden: KITLV Press, 189-216.

Butt, Simon, \& Tim Lindsey (2012) The Indonesian Constitution: A Contextual Analysis, Oxford: Hart.

Butt, Simon, \& Tim Lindsey (2018) Indonesian Law, Oxford: Oxford University Press.

Butt, Simon, \& Nicholas Parsons (2012) "Reining in Regional Governments? Local Taxes and Investment in Decentralised Indonesia." 34 Sydney Law Review 91-106.

Butt, Simon, \& Nicholas Parsons (2014) "Judicial Review and the Supreme Court in Indonesia: A New Space for Law?" 97 Indonesia 55-85.

Butt, Simon, \& Sofie Schutte (2014) "Assessing Judicial Performance in Indonesia: The Court for Corruption Crimes." 62 Crime, Law and Social Change 603-19.

Cochrane, Joe (2013) "Rebel Flag Flies Over a Province, and Indonesia Wants It Torn Down." New York Times, 14 April.

Cochrane, Joe (2017) "Trouble with Facts Plagues Indonesian Courts." Financial Review, 29 October.

Crouch, Harold (2010) Political Reform in Indonesia after Soeharto, Singapore: Institute of Southeast Asian Studies.

Effendi, Maftuh (2013) Kewenangan Uji Materil Peraturan Perundang-Undangan Dibawah UndangUndang, Jakarta: Mahkamah Agung.

Esposito, John (2017) 'Qanun' the Oxford Dictionary of Islam, http://www.oxfordislamicstudies.com (accessed 18 June 2018).

Fachrudin, Fachri (2017) "Tertutupnya Proses Uji Materiil Di MA Dinilai Rentan Penyimpangan," Kompas.com, 1 March.

Geeroms, Sofie M. F. (2002) "Comparative Law and Legal Translation: Why the Terms Cassation, Revision and Appeal Should Not Be Translated ...." 50 American Journal of Comparative Law 201-28.

Hendrianto, Stefanus (2009) "Institutional Choice and the New Indonesian Constitutional Court," in A. Harding \& P. Nicholson, eds., New Courts in Asia, London: Routledge, 158-76.

Hendrik (2014) "Umam: Investor Yang Bangun Pabrik Di Brebes Harus Taat Aturan Dan Pro Rakyat," BrebesNews.co, 10 October.

Hill, Hal (2014) Regional Dynamics in a Decentralized Indonesia, Singapore: Institute of Southeast Asian Studies.

Horowitz, Donald L. (2013) Constitutional Change and Democracy in Indonesia, New York: Cambridge University Press. 
Hosen, Nadirsyah (2010) Human Rights, Politics and Corruption in Indonesia: A Critical Reflection on the Post Soeharto Era, London: Republic of Letters.

Hukumonline (2002) "Banyak Penyebab Putusan MA Tidak Konsisten," 13 November.

Hukumonline (2010) "Banyak Putusan Kasus Korupsi Di MA Tanpa Pertimbangan Jelas," 27 August.

Hukumonline (2017) "Putusan MA: ‘Surat Edaran' Bukan Objek Hak Uji Materiil,” 11 April.

ICW (2001) Menyingkap Tabir Mafia Peradilan (Hasil Monitoring Peradilan ICW), Jakarta: Indonesian Corruption Watch.

Ismail, Tjip (2003) "Kebijakan Pengawasan Atas Perda Pajak Daerah Dan Retribusi Daerah," in R. David, ed., Decentralization, Regulatory Reform, and the Business Climate, Jakarta: Partnership for Economic Growth, 87.

Kamil, Sukron, \& Chaider Bamualim eds. (2007) Syariah Islam Dan HAM: Dampak Perda Syariah Terhadap Kebebasan Sipil, Hak Perempuan, Dan Non-Muslim, Jakarta: Center for the Study of Religion and Culture, State Islamic University Syarif Hidayatullah.

Kine, Phelim (2017) "Indonesia's Aceh Authorities Lash Hundreds Under Sharia Statutes," Human Rights Watch, https://www.hrw.org/news/2017/02/08/indonesias-aceh-authorities-lash-hundredsunder-sharia-statutes (accessed 18 June 2018).

Kristiansen, Stein, \& Purwo Santoso (2006) "Surviving Decentralisation? Impacts of Regional Autonomy on Health Service Provision in Indonesia." 77 Health Policy 247-59.

Lasser, Mitchel (2004) Judicial Deliberations: A Comparative Analysis of Judicial Transparency and Legitimacy, New York: Oxford University Press.

Lev, D. S. (1972) "Judicial Institutions and Legal Culture in Indonesia," in C. Holt, ed., Culture and Politics in Indonesia, Ithaca: Cornell University Press, 246-318.

Lev, D. S. (1978) "Judicial Authority and the Struggle for an Indonesian Rechtsstaat." 13 Law and Society Review 37-71.

Lewis, Blane D. (2003) "Tax and Charge Creation by Regional Governments under Fiscal Decentralization: Estimates and Explanations." 39 Bulletin of Indonesian Economic Studies 177.

Lewis, Blane D., \& Daan Pattinasarany (2009) "Determining Citizen Satisfaction with Local Public Education in Indonesia: The Significance of Actual Service Quality and Governance Conditions." 40 Growth and Change 85-115.

Lewis, Blane D., \& Bambang S. Sjahir (2009) "Local Tax Effects on the Business Climate," in N. McCulloch, ed., Rural Investment Climate in Indonesia, Singapore: SEAS, 224-45.

Lieberman, Samuel, \& Puti Marzoeki (2002) "Health Strategy in a Post-Crisis, Decentralizing Indonesia." Discussion Paper Series, Washington: World Bank.

Lindsey, Tim (2012) Islam, Law and the State in Indonesia, London: IB Taurus.

Litvack, J. Ilene (1998) Rethinking Decentralization in Developing Countries, Sector Studies Series, Washington: World Bank.

Lotulung, Paulus Effendie (1997) Peranan Yurisprudensi sebagai Sumber Hukum, Jakarta: Badan Pembinaan Hukum Nasional, Departemen Kehakiman.

Lubis, T (1993) In Search of Human Rights: Legal-Political Dilemmas of Indonesia's New Order, 1966-1990, Jakarta: Gramedia Pustaka Utama.

Mahkamah, Agung (2003) Blueprint for the Reform of the Supreme Court of Indonesia, Jakarta: Supreme Court of Indonesia.

Mahkamah, Agung (2015) Laporan Tahunan 2014, Jakarta: Mahkamah Agung.

Mahkamah, Agung (2017) Laporan Tahunan 2016, Jakarta: Mahkamah Agung.

Manor, James (1999) The Political Economy of Democratic Decentralization, Washington, DC: World Bank Publications.

Muhyiddin, Muhammad (2014) “Komnas Perempuan: Perda Diskriminatif Meningkat,” Tempo.co, 20 January.

Parlina, Ina, \& Arya Dipa (2013) "MA Chief Expects High Court Leaders to Combat Judicial Mafia." Jakarta Post, 3 December.

Parsons, Nicholas, \& Marcus Mietzner (2010) "Sharia By-Laws in Indonesia: A Legal and Political Analysis." 11 Australian Journal of Asian Law 190. 
Pemberton, John (1999) "Open Secrets: Excerpts from Conversations with a Javanese Lawyer, and a Comment," in V. Rafael \& R. Mrazek, eds., Figures of Criminality in Indonesia, the Philippines, and Colonial Vietnam, Ithaca, NY: Southeast Asia Program, Cornell University, 193-209.

Pompe, S. (2005) The Indonesian Supreme Court: A Study of Institutional Collapse, New York: Southeast Asia Program, Cornell University.

Pratikno (2005) "Exercising Freedom: Local Autonomy and Democracy in Indonesia, 1999-2001," in M. Erb, P. Sulistiyanto, \& C. Faucher, eds., Regionalism in Post-Suharto Indonesia, New York: Routledge Curzon, 20-35.

Ray, David (2003) Decentralization, Regulatory Reform, and the Business Climate, Jakarta: Partnership for Economic Growth.

Saputra, Andi (2017) "Timbulkan Konflik, Seluruh Uji Materi Peraturan Harusnya Di Bawah MK," Detik.com, 14 November.

Satuan Tugas Pemberantasan Mafia Hukum (STPMH) (2010) Mafia hukum: modus operandi, akar permasalahan dan strategi penanggulangan, Jakarta: Satuan Tugas Pemberantasan Mafia Hukum.

Schwarz, Adam (2000) A Nation in Waiting: Indonesia's Search for Stability, Boulder, CO: Westview Press.

Sholikin, Nur, Ronald Rofiandri, Fajri Nursyamsi, Anfidja Mauli, Simon Butt, \& Nicholas Parsons (2013) Laporan Kajian Implementasi Pengawasan Perda Oleh Pemerintah Dan Mahkamah Agung, Jakarta: Pusat Studi Hukum dan Kebijakan.

Stockmann, Petra (2007) The New Indonesian Constitutional Court: A Study into Its Beginnings and First Years of Work, Jakarta: Hans Seidel Foundation.

Tanzi, Vito (1995) Fiscal Federalism and Decentralization: A Review of Some Efficiency and Macroeconomic Aspects, Washington: World Bank.

Thoolen, Hans (1987) Indonesia and the Rule of Law: Twenty Years of "New Order" Government: A Study, London: Frances Pinter Publisher.

Wells, Michael (1994) "French and American Judicial Opinions." 19 Yale Journal of International Law 81-133.

World Bank (2004) Village Justice in Indonesia: Case Studies on Access to Justice, Village Democracy and Governance, Jakarta: World Bank.

Wulandari, Indah (2010) "Satgas Mafia Hukum Tak Diperlukan Jika Hukum Membela Kepentingan Publik." Republika, 3 August. 